Article

\title{
Fighting Injustice and Intolerance: Re-Presentations of Race and Religion at the Muhammad Ali Center
}

\author{
Michael Brandon McCormack
}

Department of Pan-African Studies and Department of Comparative Humanities (Program in Religious Studies), University of Louisville, Louisville, KY 40292, USA; b.mccormack@louisville.edu

Received: 4 September 2017; Accepted: 27 October 2017; Published: 1 November 2017

\begin{abstract}
This article explores the significance of the Muhammad Ali Center as a site where meanings associated with "race" and "religion" are constructed, contested and potentially transformed. The Muhammad Ali Center is examined as an example of an increasing number of cultural institutions (i.e., cultural centers, museums, arts spaces etc.) engaged in the strategic re-presentation of issues of cultural difference and socio-political conflict, towards the ends of promoting social justice and/or human rights. The article draws upon theories and methods in cultural studies, religious studies, and museums studies in order to explore the significance of the representational and curatorial strategies of such cultural institutions for understanding alternative approaches to influencing and/or intervening in public discourses and practices surrounding issues of racial injustice and religious intolerance.
\end{abstract}

Keywords: Muhammad Ali; cultural institutions; museums; representation; curatorial strategies; racial injustice; religious intolerance; spirituality; African American religions; cultural studies

"All of my boxing, all of my running around, all of my publicity was just the start of my life. Now my life is really starting. Fighting injustice, fighting racism, fighting crime, fighting illiteracy, fighting poverty - using this face the world knows so well and going out and fighting for truth and different causes." ${ }^{1}$

Muhammad Ali, 1991

\section{Introduction}

This article explores the Muhammad Ali Center in Louisville, KY, as a significant site where meanings associated with "race" and "religion"—as individual and communal identities and socio-cultural practices with political effects, among other possible meanings-are mediated, contested, renegotiated, and advocated. If the categories of "religion" and "race"-especially continuous social constructions, contestations and negotiations of religious and racial identities-are inextricably linked to politics, social location, and cultural orientations, then analyzing the interplay of "religion" and "race" involves understanding "cultural processes whereby individuals and groups map, construct, and inhabit worlds of meaning." (Curtis 2006, p. 7). As such, I am interested in a critical description and analysis of the ways that the Muhammad Ali Center represents those cultural processes of racial and religious identification and meaning making practices in light of the historical and socio-political contexts that shaped the life and legacy of an unapologetically black, Muslim, boxer, and humanitarian, who came to be identified as Muhammad Ali.

1 This quotation, from Thomas Hauser's Muhammad Ali: His Life and Times (Hauser 1991), is inscribed on a wall near the exit of the Muhammad Ali Center, leaving visitors to the museum with a parting, and prompting, message concerning the significance of the life and legacy of the boxer beyond the ring. 
I argue that the Muhammad Ali Center is a distinctive and significant site of analysis insofar as it self-identifies as both a cultural center and a museum that is dedicated to an heroic athlete of international acclaim (hailed as "The Greatest of All Time"), whose racial and religious identities were nevertheless considered "deviant" among many Americans during the height of his fame. (Hart 2008, pp. ix-xi, 15; Johnson 2009, pp. 145-70). ${ }^{2}$ Moreover, the Center's aims to capture Ali's symbolic status as a popular cultural icon with a thriving fan culture, who was simultaneously hailed as an emblem of global humanitarianism adds additional layers of potential meaning to the Center. Thus, I am particularly interested in the Ali Center as it represents a site of memory, cultural production, popular culture fandom, and meaning making, geographically located in the South, dedicated to a figure whose life and legacy is significantly racially and religiously charged. Moreover, the Center represents a site that is actively engaged — though strategically and at times subtly-in an agenda of social justice.

Along these lines, I am particularly interested in the potential role of the Muhammad Ali Center as an agent of social change, especially as it relates to informing and transforming public discourses on the interplay of "race" and "religion." While some scholars, such as International Human Rights professor, Jenifer A. Orange argue that cultural institutions, and museums spaces in particular, "should risk making transformational goals explicit in mission statements," (Orange 2012) the Muhammad Ali Center takes a more indirect approach, articulating its mission as follows:

The Muhammad Ali Center is a multicultural center with an award-winning museum dedicated to the life and legacy of Muhammad Ali. The Center museum captures the inspiration derived from the story of Muhammad Ali's incredible life and the Six Core Principles that fueled his journey. ${ }^{3}$

The Ali Center's articulation of its mission statement represents the tension that many museums and cultural centers and their leadership wrestle with concerning the social purpose of such institutions and their role in advocating social change. Traditionally, museums have opted to adopt a "neutral" or "objective" posture that avoids the appearance of advancing a political agenda or "taking sides" in various "cultural wars." However, other institutions have been more explicit about stating a moral position on issues such as human rights. The Ali Center attempts to negotiate this philosophical divide by not foregrounding a stance of political advocacy in its official literature, while engaging social issues and taking a decidedly inclusive, global, and humanitarian stance on cultural difference in its representational and curatorial strategies.

At stake in such negotiations is clearly the issue of alienating potential donors and visitors by promoting an overtly politicized message. There are also philosophical and epistemological concerns at play as well, which include considerations of the most effective pedagogical approaches to communicating the mission of the Center in a manner that is likely to result in socio-political effects that are in line with the Center's mission. I argue that though "race" and "religion" are not explicitly named in the Muhammad Ali Center's official mission statement, they are nevertheless critical categories that are strategically and continuously re-presented and re-negotiated in order for the Center to achieve its purposes. These purposes include making use of the cultural capital of the figure of Ali as an inspiration for social transformation oriented towards the achievement of a more

2 William D. Hart describes a "Standard Narrative of Black Religion," that renders "deviant" those religious traditions, beliefs and practices that fall outside of the black Protestant Christian norm. Hart uses the language of Afro-eccentricity to describe those individuals, institutions, and communities whose religious identifications transgress this "standard narrative." See William D. Hart, Black Religion: Malcolm X, Julius Lester, and Jan Willis (Hart 2008). For a similar argument, see also Sylvester A. Johnson, "Religion Proper and Proper Religion: Arther Fauset and the Study of African American Religions" in New Black Gods: Arthur Huff Fauset and the Study of African American Religions, Edited by Edward E. Curtis IV and Danielle Brune Sigler (Johnson 2009; Curtis and Sigler 2009); See also Sylvester A. Johnson, African American Religions, 1500-2000: Colonialism, Democracy, and Freedom (Johnson 2015, pp. 377-400).

3 The mission statement for the Muhammad Ali Center was accessed on the Center's web page: http://alicenter.org (accessed on 15 June 2017). 
just and inclusive society where individuals and communities can reach their fullest potential—or "Be Great: Do Great Things"-irrespective of the particularities of their race, gender, class, sexual orientation, religion or other markers of social or cultural difference. ${ }^{4}$

This analysis of the Muhammad Ali Center represents the initial work of an ongoing research project, examining the role of cultural institutions-including cultural centers, arts spaces, museums, and other such venues-in representing (and/or performing) various African American religious beliefs, practices, institutions, and experiences. ${ }^{5}$ Taking a cultural studies approach to the study of African American religions, I am concerned, in this project, with the cultural and representational politics involved in exhibiting African American religions in these cultural institutions. Furthermore, I am especially concerned with understanding how, if at all, such cultural work influences public discourse (and thus the continual construction and contestation) surrounding these religious traditions. Moreover, this research inquires into the social effects and political implications of the modes of cultural work, related to African American religions and cultures, performed in and through these institutions.

Along these lines, I question how the strategic and critical use of the arts, tactical displays of (material) cultural artifacts, performative actions, educational and programmatic initiatives in and through these public institutions might open angles of inquiry and encourage transformative dialogue and/or debate within and between diverse communities around potentially volatile subjects of social concern, such as issues of ongoing racial injustice and religious intolerance. Indeed, I am interested in whether and how these spaces might facilitate a quality of understanding, dialogue and debate around issues surrounding African American religion and culture (and "race" and "religion" more broadly) that might otherwise be foreclosed or constrained by other modes of academic, public, and/or political discourse. Put another way, this research is interested in the role of cultural centers, museums, and the like in representing African American religions and cultures, and the potential of such representations for social transformation toward a more just and inclusive society. Thus, in this particular article, I am interested in the Muhammad Ali Center, not only as an intriguing site for understanding how "race" and "religion" are socially constructed and culturally represented, but also as a potentially transformative site of ideological struggle over social understandings of cultural difference at the intersections of "race" and "religion" (as well as gender, sexuality, etc.) (Coffee 2006, p. 435). ${ }^{6}$

\section{Theoretical and Methodological Considerations}

Of course, museums are not often thought of in terms of their role as agents of change. More often, they are critiqued as sites of cultural hegemony or "stilted, authoritative, controlling, and exclusionary sites." ${ }^{7}$ However, as Richard Sandell and others have noted, "museums are becoming more aware of themselves as agents of positive and negative social change," and thus recognizing and embracing their moral obligations and/or social responsibilities to engage pressing social issues of public concern (Sandell 2012, p. 197). Moreover, Sandell observes in Museums, Prejudice and the Reframing of Difference, that a range of intellectual discourses including museum studies,

4 Richard Sandell offers a fine treatment of the various positions and stakes in the internal debates among museum theorists and practitioners in Museums, Prejudice and the Reframing of Difference (Sandell 2006).

5 This research began as a project with generous funding from The Wabash Center for Teaching and Learning in Theology and Religion. As a part of this project, I have identified a handful of sites that have treated different expressions of African American religion and culture (i.e., Christianity, Islam, Yoruba). This project is concerned, not only with the representational practices of these cultural institutions, but it also inquires into the pedagogical function and significance (academic and public) of cultural centers, museums, and other similar sites in informing, and potentially transforming, public discourse and practice concerning the interplay of "race" and "religion" in the United States.

6 Coffee argues that while museums are not necessarily as influential as other forms of culture and popular media, they are nevertheless significant sites of public influence as museums are "important collections of ideological symbols," which are often highly contested (Coffee 2006, p. 435).

7 See, Darlene Clover (Clover 2017), "Exhibitions of Power: Participatory Visual Practices in Contemporary Museums," in New Directions for Adult and Continuing Education, no. 154, Summer 2017, 89. See also, Coffee (2006), "Museums and the Agency of Ideology." 
sociology, cultural anthropology, and cultural studies, have "thoroughly positioned museums as sites in which social understandings of cultural difference are negotiated, constituted, and communicated." (Sandell 2006, p. x). Scholars pursuing this line of inquiry question the potential of museums (and presumably other similar cultural institutions) to "function as sites for the staging of liberatory interventions designed to contest or subvert dominant (oppressive, discriminatory) understandings of difference." ${ }^{8}$ Sandell reminds us, however, that while scholarly accounts of the museum as an agent of social change remain contested, "there is nevertheless growing interest in the adoption of purposes and functions which position museums as institutions which can be brought to bear on 'the social' in various ways." (Sandell 2006, p. xi).

To the degree that museums, which have historically been the most conservative of the cultural institutions that I am considering, are beginning to embrace their responsibility as change agents, the question remains: how do they attempt to accomplish this task? In order to get at answers to this query, I engage the work of scholars working at the intersections of museum studies, cultural studies, cultural anthropology as well as other disciplines, paying attention to the theories and methods they deploy in an attempt to describe and analyze the distinctive interventions that museums and other cultural institutions make. As media studies scholar, Steven C. Dubin reminds us, "Examining culture is never simply a case of 'what you see is what you get.' Reaching a thorough understanding of cultural phenomena requires conducting several layers of analysis." (Dubin 1999, p. 11). While there is no singular approach to such research, scholarly inquiry includes approaches that describe and analyze the cultural productions, representations, curatorial practices, programmatic initiatives and other interventionist strategies, attempting to decode the meanings encoded in such spaces and practices and how they function to disrupt, challenge, and/or encourage alternative ways of viewing politically charged issues.

In her work, Strategies of Display: Museum Presentation in Nineteenth-and Twentieth-Century Visual Cultural, Julia Noordegraaf uses the language of "script" to describe "a useful tool to analyse the complex relations between the intentions of the [museum] designers, the objects themselves and their potential or imagined users." (Noordegraaf 2004, p. 15). For Noordegraaf, numerous aspects of a museum space combine to constitute its "script," including "location, the architecture and layout of the building, the organization and design of the displays and the means of visitor guidance." (Noordegraaf 2004, p. 16). Of course, there are also discursive and ideological aspects at play in a museum's design and curated exhibits, which demand attention as crucial elements of a museum's "script."

To be sure, though, scripts encoded or inscribed by agents of the museum are only a preferred mode of engaging the museum space. Visitors to the museum may move through, engage, and/or interpret the space and exhibits in ways that mirror the intentions of the "invisible script." (Dubin 1999; Noordegraaf 2004; Sandell 2006; Clover 2017). However, patrons may also resist, misread, or otherwise thwart the desired engagement with the museum's script. In a similar vein as Sandell, Noordegraaf argues for a mode of analysis, which she calls "description," that works to expose the "strategies of display" deployed by museum designers and curators, as well as the ways that visitors encounter, read, make meaning of, reinterpret and/or resist such scripts. Sandell's work represents an approach that places greater emphasis on analyzing audience reception, meaning-making, responses to, and uses of museum "scripts," or the intended meanings encoded in exhibits. Kevin Coffee also calls for greater attention to the political implications of the programming decisions of museums, as these decisions "demonstrate the ideological purpose of the museum." (Coffee 2006, p. 435).

My current research draws upon the work of theorists such as Sandell, Noordegraaf, and Coffee and a range of theorists of religion and culture (Curtis 2006; Hart 2008; Glaude 2014) in

8 Ibid., p. x. Sandell notes the current trend in this direction towards social agency, responsibility and advocacy in international museums, versus the more "impartial curatorial voice" (p. 59) that museums have attempted to portray in the past. 
order to analyze the potential of museums and other cultural-arts centers, to intervene on public discourses (and affect political policies) concerning issues of "race" and "religion" in the United States. For instance, how do such institutions, through their representational strategies, curatorial practices, and other programmatic initiatives, offer alternative perspectives on "race" and "religion" than those encouraged by other institutions and discourses? African American Religion scholar, Eddie S. Glaude Jr., has argued: “How we talk about African American religion, how we account for the myriad ways in which a diverse, racialized group gives expression to their religious beliefs within institutions that constitute a kind of cultural inheritance requires a different language." (Glaude 2014, p. 117) For Glaude, "new languages would have to emerge to describe and account for black religious experiences under the shifting conditions of late capitalism and the evolving status of race in the United States." (Glaude 2014, p. 117) In this research, I am interested in how cultural institutions such as the Muhammad Ali Center might be contributing to the development of "new languages," discourse, and/or approaches to African American religions and culture that facilitate different understandings of these traditions. Moreover, I am interested in what pedagogical and political functions the distinctive languages or discursive representations of African American religion encoded into the "scripts" of such institutions and practices might serve in raising critical consciousness, shifting public opinion, and catalyzing social transformation.

Along these lines, this particular article is primarily concerned with performing a critical description of the representational, curatorial, pedagogical, and other strategies of intervention deployed by the Muhammad Ali Center to engage issues of racial injustice and religious intolerance. This work of descriptive analysis also considers the usefulness of these particular interventionist strategies for ongoing ideological struggles over contested issues of race and religion that advocate for a more just and inclusive socio-political agenda. With reference to the Muhammad Ali Center, I am interested in performing such a description with a particular emphasis upon how the "strategic display" of, and curatorial strategies involving issues of "race" and "religion" are encoded into the museum's "script," and how this script is intended to affect public opinion on these contentious matters.

In addition to the theoretical framing of this work, drawing up museum studies, cultural studies, and religious studies, data collection and analysis for this research project has involved multiple visits to the Ali Center, hours of viewing various permanent and temporary exhibits, informal interviews with curatorial and programmatic staff as well as the Center's CEO. It has also involved informal observation and dialogue with visitors as they interact with various exhibits in the Center. To be sure, additional research that more formally engages audience receptions and uses of the meanings encoded or "scripted" into the Center's exhibitions and programmatic initiatives will be necessary to gain a fuller sense of the socio-political effects of the cultural work performed by the Muhammad Ali. For the purposes of this article, and given the initial stages of the research, however, this article will be limited to a performance of critical description and analysis of the representational and curatorial strategies employed by the Ali Center to engage issues of "race" and "religion" associated with Ali's embrace of (the Nation of) Islam.

\section{A Brief Orientation to the Muhammad Ali Center}

The Muhammad Ali Center is located near the banks of the Ohio River in downtown Louisville, KY, the late Ali's hometown. The Center opened its doors to the public on November 1, 2005 after nearly a decade of fundraising and planning. In collaboration with Ali and his wife Lonnie, the initial plans for the Center sought to preserve the life and legacy of the legendary boxer, both inside, and more importantly, outside of the ring. Moreover, the Center was imagined as an international public gathering space for people from around the globe to draw inspiration from Ali to "Be Great: Do Great Things." ${ }^{\prime 9}$ Indeed, a large sign scaling the outside wall of the Ali Center greets visitors with an image of,

9 See http://alicenter.org. 
and message from, Ali that reads, "For many years I have dreamed of creating a place to share, teach, and inspire people to be their best and to pursue their dreams." The museum's motto and strategic display of this quote from Ali can be understood as the Center's encouragement and advocacy of the full realization of human potential, irrespective of the particularities of social location and cultural identification. Of course, this carries an implicit critique of those social, political, and ideological positions that undermine such imaginings of human flourishing among marginalized and oppressed people, though this more politicized message does not become apparent until visitors engage the exhibits displayed within the Center.

Upon entering the nearly 100,000 sq. ft. Muhammad Ali Center, visitors take a steep escalator (described by museum tour guides as the second longest escalator in the state of Kentucky) to the fifth level, the starting point of the tour of five descending levels of exhibits and displays. During this approximately one-minute-long escalator journey, visitors encounter messages of "welcome" translated into more than a dozen different languages inscribed upon the walls. These multilingual messages of "welcome" can be understood as part of the Center's strategic "language of display," designed to communicate a message of hospitality for all visitors. It also signals the global humanitarian emphasis of the Center, as a way of interpreting the international status and significance of Muhammad Ali's career beyond the boxing ring.

After ascending to the height of the Center, visitors are encouraged to begin their tour by viewing a dramatic, five-screen multimedia film presentation, entitled "If You Can Dream," which is narrated by James Earl Jones and Maya Angelou. ${ }^{10}$ After viewing the approximately fifteen-minute film in the Orientation Theater, which provides what can be described as an "inspirational" framing of Ali's life and legacy, visitors enter into the exhibit space of the museum in order to be more fully immersed in the historical, cultural, and socio-political contexts that shaped Ali. Four interactive "Journeylines," narrated by $A B C$ News anchor and Louisville native, Diane Sawyer, are positioned at various points throughout the fifth level. ${ }^{11}$ These Journeylines provide a chronological account of Cassius Clay's/Muhammad Ali's life, highlighting significant events in his boxing career, but also selected historical and biographical narratives deemed to be significant for understanding his developing racial consciousness and religious conversion(s). ${ }^{12}$

Visitors following the preferred route of the official Muhammad Ali Center Visitor Map \& Guide, and the spatial design of the Center, initially encounter a series of exhibits curated around "Six Core Principles," which are presented as normative values guiding Ali's life. The six core principles are constructed and employed by the Center as a primary framing device for encouraging a particular interpretation of the complex life and legacy of Muhammad Ali. The core principles are defined by the Center as: (1) Confidence-belief in oneself, one's abilities, and one's future (2) Conviction-a firm belief that gives one the courage to stand behind that belief, despite pressure to do otherwise (3) Dedication - the act of devoting all of one's energy, effort, and abilities to a certain task (4) Giving — to present voluntarily without expecting something in return (5) Respect-esteem for, or a sense of the worth, or excellence of, oneself and others (6) Spirituality-a sense of awe, reverence, and inner peace inspired by a connection to all of creation/or that which is greater than oneself. ${ }^{13}$ Notably, these core principles are strategically positioned within the museum space to encourage an encounter with

10 According to the Muhammad Ali Center Visitor Map \& Guide, "If You Can Dream," is framed around the poem, "If," by Rudyard Kipling, which Ali is said to have carried in his wallet for inspiration.

11 Muhammad Ali Center Visitor Map \& Guide.

12 For instance, the first narrative encoded into the script of the initial Journeyline (1942-1957) calls attention to the influence of the religio-political race man, Marcus Garvey, upon Cassius Clay's father. This initial narrative signals the historical and socio-political context in which race matters for the subject formation of young Cassius Clay, and its implications for his life and legacy as Muhammad Ali.

13 Further information on the function of the "Core Principles" within the Center can be found on the Muhammad Ali Center webpage: http: / / alicenter.org (accessed on 15 June 2017). 
these socially and politically inflected exhibits before moving on to exhibits dedicated to Ali's boxing career, proper.

Within the official literature of the Muhammad Ali Center, the articulation and representation of Ali's "core principles" does not immediately reveal a contestation over social norms, however, upon closer examination, it becomes apparent how the Center deploys these "core principles" in unexpected ways that disrupt taken for granted assumptions concerning cultural differences. It is important to briefly note, at this point, that scholars of museology have described the power dynamics involved in museums' representation (whether explicitly or implicitly) of some perspectives as representative of the "core" of the institutions values and others as more "marginal." (Younge 2012, pp. 105-13) To classify a principle as a "core principle" is to classify it as deserving of public attention in ways that other principles may or may not be. While many museums have been critiqued for constructing a set of "core" values that reinforce dominant cultural norms and power dynamics, a growing number of cultural institutions have "scripted" their core values in such a way that highlight communities and perspectives that have historically been excluded from such spaces. Such a re-articulation of the "core" and the "margins" is a means by which museums challenge normative assumptions in society. Below, I will describe how the representational and curatorial strategies framing four of the core principles-Confidence, Respect, Conviction, and Spirituality—work to show how "race" and "religion" function to construct particular subject formations in Ali and in visitors as well. Through such strategies, the Center invites and encourages visitors to consider alternative ways of viewing the constructed, mutually constitutive, and contested categories of "race" and "religion."

\section{4. "Who Is the Greatest?" Representing Black Self-Confidence as a Defiant Challenge to the Ideological "Religion" of White Supremacy}

The Confidence exhibit is strategically positioned to be the visitor's initial encounter with the core principles, and indeed among the first displays to be engaged once visitors exit the Orientation Theater. Each of the core principles exhibits is marked by a large floor-to-ceiling sign, which displays images of Ali, multiple languages, and an interpretation of the specific core principle. These signs function, not only as guideposts or points of entry that orient visitors to the exhibit space, but also to encourage a particular interpretation or understanding of Ali's life and legacy in light of the specific core principle. Thus, these signs can be understood as framing devices, and interpretive cues that work in tandem with the Journeylines, curated exhibits, and other strategic displays to encode the museum's "script." The sign that marks the entrance to the Confidence exhibit begins with an "inspirational" personal message to viewers, encouraging them to, "Know who you are and believe. Trust yourself: let yourself take the steps that get you where you want to go. Sometimes this requires a leap of faith." While this initial message is designed to appeal to the personal, and perhaps individualistic, interests of a wide variety of diverse visitors, a more socially conscious message is subtly interwoven, preparing visitors for an encounter with the political implications of "confidence" among marginalized people in an oppressive society. This socially and politically inflected message, however, is introduced through a more subtle appeal to the personal narrative of Ali: "The self-confidence that Muhammad Ali showed the world irritated some people. But it inspired —and empowered-many, many others."

The Confidence exhibit is designed as an audio-visual presentation, displayed as a short film projected onto a large panoramic screen. The construction of the exhibit space invites visitors into the dimly lit area, where they can stand or enjoy limited seating for the film presentation. At the beginning of the presentation, a seemingly benign inquiry, "Who is the greatest?" appears on the screen, prior to any audible dialogue in the film. "Who is the greatest?" is posed as a framing/interpretive device to encourage a particular interpretation of the "script" that this film is intended to present. The film's "script" can be understood to function in a pedagogical manner, working to establish the socio-cultural context in which Ali's own boastful claims, such as, "I am the greatest!" and "I'm pretty!" can be understood as racially and politically charged statements of self-affirmation. While patrons may be familiar with Ali's more bombastic rhetoric, the filmic exhibit works to defamiliarize, and thus to 
politicize, such proclamations by contextualizing them within a long history of anti-black discourses and practices. Such contextualization reveals the political charge of such claims to "greatness" for a poor, black, kid from Louisville, for whom access to socially constructed norms of "greatness" was systemically denied through white supremacist pretentions and attempts at the monopolization of the material and existential resources of "excellence."

Yet, viewers are immediately introduced to black celebrity figures and everyday folks alike, who bear witness to their experiences of the social construction and treatment of blacks as "subhuman," and the ways that everyday existence in a system of unrelenting white supremacy, "takes a toll on you," to the point where, "I got no confidence." Moreover, the film works to expose the hegemony of Eurocentric standards of beauty, which privilege the worth and value of white bodies and features. By giving voice to a young black woman representing the era of the 1950s-1960s who confesses, "I see what I've been trained to see," and "I don't see nothing I like," the film raises critical questions concerning the politics of "seeing," and the ways that oppressive social formations "train" our eyes to see in ways that affirm dominant values, while undermining the self-confidence of those subjects marginalized within this social order. Testimony from African Americans describing negative assessments of their black bodily features, including nose, lips, and "nappy hair" are audibly described, in order to impress upon visitors the denigration of black bodily aesthetics. Images of skin lightening cream are displayed during the narration to impress upon viewers the extent to which many African Americans of Ali's era had succumbed to self-denigration. ${ }^{14}$ It is against this backdrop of black internalized oppression that Ali's proclamations of his own "beauty" and "prettiness" are presented as transgressive self-affirmations beyond mere boasting.

Moreover, Ali's bold proclamations of his greatness are interspersed with commentary from other African Americans describing the perception at the time that "to be too black was to risk your life." To reinforce this perspective, images of Emmett Till—the slain youth, falsely accused and murdered by a racist mob in the south determined to teach him his "place"-are displayed on the screens. Simultaneous with those images of Till, oral testimonies from the film's commentators describe parental advice to black children during that era. For example, children were warned, "don't talk too loud ... don't wear loud colors," and other imperatives intended to increase the chances of their children's survival. These testimonies are employed to demonstrate how such strategies of self-abnegation, for the sake of survival, came at the expense of African Americans' sense of self-worth. The film's portrayal of Ali's defiant insistence of his greatness calls attention to how Ali's example of personal and racial pride-including his willingness to speak up for himself and his people-" gave young black kids something to look up to," and made others who had been denigrated by white supremacy "want to be great." When the video concludes with an anonymous black male stating, "A confident black man ... it's what we all should be. The world better get used to it," viewers exit the space having encountered a powerful message about the injustices of racial superiority, the debilitating effects of internalized inferiority, and the socio-political significance of Ali's counter-hegemonic confidence.

Yet, viewers exit the space with more than a lesson on the damaging effects of hegemonic whiteness on black racial identity formation and Ali's remarkable defiance of such social norms. This initial exhibit also foreshadows the core principle of Spirituality, offering a preview of Ali's critique of white supremacist constructions of Christianity and its role in reinforcing black internalized oppression. Visitors encounter footage of Ali explaining, "We were taught that everything good was white and everything bad was black. Even Jesus Christ and the angels, we see white. The Last Supper we see

14 In Black Muslim Religion in the Nation of Islam: 1960-1975, Edward E. Curtis IV relates a testimony of Ermine X Lowe, a convert to the Nation of Islam, who bears witness to the significance of testimonies and images displayed the Confidence exhibits' video. According to Curtis, Lowe testifies, "We find, under the impact of Islam, that it is indeed a divine blessing to be unique- and our hair and color help make us that. As Christians, we feel so ashamed of the blessings God has given us, in His wisdom, that we bleach our skins and suffer any kind of indignity or hardships to make ourselves look like some grotesque caricature of our open enemy ... Only through love of self and kin ... can one achieve self-respect" (Curtis 2006, p. 110). 
white ..." With this initial exhibit, not only is Ali's confidence contextualized, but his later critique of dominant normalized understandings of "religion," as circulated by Euro-centric interpretations and representations of Christianity, is highlighted, foreshadowing his eventual embrace of Islam as his spiritual path. In this sense, the representational and curatorial strategies of the exhibit can be seen as displaying the social effects of constructing "whiteness" as a sacred object of (religious) devotion, while constructing "blackness" as a profane manifestation of immoral "deviance" and "danger."

Early on in the museum, then, visitors are presented with testimonials intended to promote a more empathetic understanding of why many African Americans, such as Ali, were initially attracted to religious alternatives to Christianity. As such, this exhibit works to prepare visitors for Ali's eventual embrace of Islam as an alternative to Christianity, which was associated with black suffering and white racism. Indeed, as Edward Curtis IV has noted, many converts to the Nation of Islam testified that they had previously "suffered from a lack of self-esteem [but] found that Islam offered a way out of a psychological depression or alienation." (Curtis 2006, p. 25). Through the Confidence exhibit, visitors are encouraged to appreciate how, at least in part, it was (a racialized expression of) Islam that undergirded Ali's racial pride, serving as a resource for resisting white supremacist assaults on black humanity, which were intended to destroy black self-worth and self-confidence.

\section{5. "All White Men Are Devils": Representing Black Religious Nationalism as a Performance of (Dis-) Respectable Black Manhood}

If the Confidence exhibit encourages an appreciative understanding of the racial and religious dynamics involved in Ali's profound sense of self-respect, the Respect exhibit displays how the interplay of racial respectability and religious resistance informed a public performance of Ali's respectable black manhood that many Americans had difficulty admiring, and others found as grounds for fear and outright resentment. ${ }^{15}$ In this exhibit, some of the more shocking aspects of the teachings of Elijah Muhammad and the Nation of Islam (NOI), concerning the status of white Americans and women are put on display. From the outset, the signage that introduces the exhibit cues visitors toward an interpretation of Ali's views concerning the complex relationships between race, religion, gender and respect that encourages a more tolerable or favorable reading of seemingly inflammatory and/or contradictory views that might alienate some patrons to the Center. After being presented with a scripted message, offering a normative assertion that "Respect thrives in an atmosphere of equality and withers in the presence of discrimination," visitors are encouraged to hold in tension Ali's early tendencies to "lash out" in ways described as "anything but respectful" when he felt disrespected with his later, more "mature," views demonstrating his respect for all of humanity.

15 This exhibit can be better understood in light of the socio-political significance of respect (-ability) for African Americans in the United States. To be sure, Ali's adherence to the Nation of Islam-with its insistence on proper decorum, "clean living," and the like-signals a mode of religious respectability distinctive from, but not unrelated to such politics practiced by his black Christian counterparts. As Eddie Glaude reminds us, "The (NOI) took up the politics of respectability that so animated the black middle class and insisted that, with Islam, the 'rejected and despised' could be remade and saved (See Glaude 2014, p. 110, African American Religion). Nevertheless, Ali's embrace of a racialized expression of Islam, which never shied away from acerbic assaults on white supremacy, positioned him beyond the bounds of normative modes of respectable blackness. And, it is this refusal of black middle-class Christian respectability that is one of the most challenging aspects of Ali to curate in the Center without risking the alienation of many patrons who might take offense at Ali's stinging religio-political rhetoric. Indeed, Ali's relationship to the Nation of Islam (NOI), described by the FBI in 1962 as, "an organization which is violently anti-white, anti-Christian, anti-integration and anti-United States," (Quoted in In the Name of Elijah Muhammad: Louis Farrakhan and the Nation of Islam (Gardell 1996, p. 5)) poses a particular challenge to the Center that bears his name and purports to honor his life and legacy as a model of American and global heroism. Nevertheless, the Muhammad Ali Center presents these potentially divisive aspects of Ali, allowing patrons to wrestle with these uncomfortable as it is presented within the broader scope of Ali's life's journey. For a discussion of religion and racial respectability politics, see Evelyn Brooks Higgenbotham, Righteous Discontent: The Women's Movement in the Black Baptist Church, 1880-1920 (Higgenbotham 1993, pp. 185-230). For a more recent discussion of respectability politics, see Brittany Cooper, Beyond Respectability: The Intellectual Thought of Race Women (Cooper 2017). See also Edward Curtis' account of religious respectability in Black Muslim Religion in the Nation of Islam: 1960-1975. See especially his chapter, "The Ethics of the Black Muslim Body," (Curtis 2006, pp. 95-130). 
To be sure, the Respect exhibit invites visitors to contend directly with Ali's more provocative statements on race and gender, rooted in his adherence to the teachings of the Honorable Elijah Muhammad and the Nation of Islam. If visitors have been attentive to the Journeylines along the preferred route of the Center, they will have already encountered interactive exhibits that detail young Cassius Clay's initial exposure to the Nation of Islam, the aspects of its teachings that attracted him, his conversion and subsequent rejection of his "slave name," and his reconstructed racial and religious identity as a "Black Muslim" minister. It is not until this exhibit, however, that visitors actually hear Ali articulate some of the more controversial views of the Nation of Islam. Thus, it is this exhibit that captures the simultaneous attraction and aversion that marks many Americans' view of Ali.

This contradictory response is demonstrated through the display of Ali's persistent demand for public respect of his shifting racial and religious identities. Ali's demands for public respect are juxtaposed with his rhetorical "disses" (read: disrespect) of whites, Christians, and women in a similar manner as he taunted and belittled his opponents in the boxing ring. In the nearly six minute video shown in this exhibit, Ali demands "respect" from his opponents in the ring and the media, alike, in various ways. Chief among them was his insistence that he be called by his Islamic and not his "slave" name. As Edward Curtis reminds us, "proclaiming Muslim identity and name (was) a bold form of self-identification (and self-respect) ... (and) was a powerful cultural and political statement in the 1960s and 1970s." (Curtis 2006, p. 178). With this in mind, it is important to consider how the Respect exhibit presents an Ali who, in keeping with the black nationalist gender politics of the Nation of Islam, was unwilling to tolerate any form of disrespect, especially from whites, and more specifically from whites identified as Christian. In the film footage displayed in the exhibit, Ali verbally spars with a white media personality, asserting, "The Christian Bible teaches that all white men are devils," and the "fact" that "white people hate black people." At one point, Ali insists that he "really believes" that all white people are devils, even as he later concedes, with characteristically playful banter, that he knows the host is "alright" (read: an exception to the rule of racist white men).

Moreover, in this footage, Ali can be seen performing the role of the "strong black man" who relegated the women in his life to a silent and supportive role in public. In one scene, a reporter poses a question to a woman accompanying Ali, and Ali can be seen reminding the woman and the reporter of his prerogative, as "strong black man," to decide when and where she should speak or enter into public discourse. Along these lines, the exhibit displays the combined influence of sexist strains of black nationalist and Nation of Islam ideologies on Ali's gender politics: "I'm a man. Somebody's got to wear the pants and somebody's got to wear the dress. There ain't gon' be no equality." At another point in the film, visitors are confronted with some of Ali's most ideologically driven and oppressive expressions of the Nation's black nationalist religious rhetoric concerning women: "I think a woman's useless if she can't reproduce a man's generational future."

As this brief descriptions shows, the curatorial strategies of the Ali Center do not eschew the most controversial aspects of Ali's legacy, which center around the nexus of race, religion and gender politics. Indeed, the exhibit invites viewers to wrestle with some of the more contentious issues surrounding matters of race, religion, and gender as they are considered within a broader conversation of diversity, equality, and social justice. (Orange 2012, p. 379). That said, a critical viewing of the video footage in the Respect exhibit suggests a particular framing of Ali's provocations intended to make them more understandable, if not palatable to patrons to the Center. Textual cues are included in the video during more provocative exchanges between Ali and his interlocutors on issues of race, religion, and gender. For instance, "Self-respect can't be obtained at the expense of someone else," is flashed onto the screen early on, while later, visitors are reminded, "Respect is born in equality ... not in fear ... " These cues culminate with a message encouraging visitors to adopt the position that "Respect is to acknowledge the worth of others, and to express it."

In addition to these textual interpretive cues, prominent (white, male) celebrity figures are employed to offer commentary on Ali's controversial racial and religious views. In the footage, Billy Crystal states flatly, "There were times that I didn't like him." As such, Crystal's commentary 
strategically gives voice to potentially negative responses from viewers who may be made uncomfortable by the socio-political and religious views of a man that they might otherwise admire as an athletic hero. Crystal offers explanations for Ali's provocative views on race and religion, such as, "It was an angry time in conversion," and later that such views "came out of a side of him that wasn't fully formed yet." In Crystal's analysis, Ali "probably regrets some of that now, and I admire that too." A former trainer, Angelo Dundee, also offers an admiring account, suggesting that his early views on race and religion reveal an Ali that is "incredibly human." Robert Lipsyte offered yet another commentary surmising that Ali should be judged, not only by his early views, but by the growth and development of ideas that Ali would come to articulate later in life. This strategy of employing a range of non-black, male, commentators who identify as personal or professional associates of Ali, functions to provide a potential point of identification for viewers who may not share or sympathize with the racial or religious views that Ali articulated during his years in the Nation of Islam.

Moreover, Ali's evolving views on "respect" as it relates to race, religion, and gender are presented as a process of (spiritual) "maturation." Ali's own demands of "respect" for himself, black people, and the religion of Islam are held in tension with his illiberal "disrespect" of "white devils" and women, before narrating the later Ali's "spiritual maturation." The "spiritually mature" Ali articulates a heightened sense of respect for all of humanity, resulting from his deepening adherence to the tenets of Sunni Islam. Towards the end of the film, both Ali and his wife, Lonnie Ali, are featured bearing witness to Muhammad's growth with regard to race and gender politics. As such, Ali's shift from an adherence to a narrow black nationalist set of religious beliefs and practices, to a more expansive Islamic spirituality, which undergirded his global humanitarianism, is presented as "a testament to growth, maturity, and change." Indeed, Ali's quote, "a man who views the world the say way at 60 as he did at 30 has lived and wasted 30 years of his life," is strategically deployed at the beginning and end of the film as a framing device to encourage a more empathetic interpretation of Ali's more radical rhetorical performances of racial and religious identification.

This appeal to "spiritual maturation" can be understood as an interpretive device to encourage visitors to adopt a "scripted" and preferred meaning of the more challenging or "negative" aspects of Ali's early religious identity and rhetoric. Though this process of maturation and expansion is highlighted in this exhibit, it is not fully expounded upon until visitors encounter the Spirituality Pavilion. To foreshadow this fuller treatment of Ali's evolving spiritual beliefs and practices, however, a strategically selected quote from Ali closes the audio-visual presentation: "Change is an inevitable part of life. Life is easier when we accept these changes and recognize how every moment of our journey is an important part of the growth of our soul." If the Confidence exhibit functioned to encourage an appreciative view of Ali's racial and religious identifications in light of internalized black oppression, the Respect exhibit displays Ali's public performance of the more acerbic rhetoric of the Nation of Islam as socially undesirable and a poor example of racial, religious, and gendered relationality. Nevertheless, visitors are offered a narrative of redemption that positions Ali as a model of the possibility of maturation beyond one's own prejudices. In this sense, this particular exhibit can be understood to promote and encourage a sense of mutual understanding, and indeed, "respect," among diverse groups of visitors, especially those who may feel estranged from one another on the basis of "race," "religion," or "gender."

\section{6. “Standing up for My Religious Beliefs!": Representing Conscientious Objection as Religious Conviction and Solidarity with Oppressed People of Color}

After a moment of potential resolution in the Respect exhibit, wherein visitors have been encouraged to appreciate a more universalist interpretation of Ali's appreciation for the equality and worth of all human beings, the exhibition of Conviction thrusts patrons back into the particularities of Ali's persistent views on the politics of race and religion in the United States. Ali's deepest "convictions," rooted in the "identity and inspiration" that Ali "discovered ... in an unconventional religion," are contextualized in light of the tumultuous politics of the 1960s. To be sure, the Conviction 
exhibit is undoubtedly the most extensive, as well as politically and emotionally charged exhibit. Before entering the exhibit, designed as a lengthy corridor filled with an overwhelming amount of visual and aural stimuli, visitors are cued toward an individually inspiring interpretation of the exhibition, "Be true to yourself: take a stand." Yet, visitors are also reminded that such convictions often demand considerable courage in the face of social norms and political pressure and may require significant personal and professional sacrifice.

Upon entering the exhibit, visitors are immediately confronted with various "strategies of display" intended to convey the climate of racial hostility that marked the turbulent decade of the 1960s. A replica lunch counter is positioned in the entrance of the exhibit where visitors are accosted by a hostile voice of unwelcome when attempting to enter the space. On the lunch counter, visitors can observe replica artifacts from local accounts of racial politics and struggles that shaped the Louisville community that shaped Ali. Following this disruptive encounter with local politics, visitors enter a corridor curated with an assemblage of socio-political images, artifacts, and cultural productions representing national and international political struggles of the era. For instance, visitors encounter a display of several protest signs inscribed with provocative political messages, representative of the era, such as "America is a Police State for the Black Man." Juxtaposed to these signs and other visual representations of political contestation, screens displaying video footage of racial riots, protest movements, biting political rhetoric, and more create an especially charged atmosphere in the Conviction exhibit. Racial prejudice and its radical resistance is laid bare in audio-visual displays as well as visually rich print material voicing quotations of anti-black sentiments of the day.

An overabundance of quotations and interpretive devices are inscribed on the walls, including a range of political perspectives and opinions. Recordings of the strident voices of white provocatuers, as well as black radicals_-from Malcolm X to Angela Davis—can be heard as visitors engage exhibits throughout this section of the museum. Quotations from the likes of Elijah Muhammad and Ella Baker, Martin Luther King Jr. and John F. Kennedy, Stokely Carmichael and Kathleen Cleaver line the walls along with provocative representations of the material culture of the times. In this space, visitors are expected to do the difficult work of deciphering and interpreting a range of conflicting messages, while keeping in mind the strength of conviction that Ali exhibited in articulating and maintaining a moral stance in the midst of such uncertain times. Put another way, the Center strategically represents a multitude of conflicting voices, creating a cacophony of perspectives and opinions, while positioning Ali as a model of unwavering conviction in the midst of shifting public opinion and socio-political pressure to compromise his beliefs.

Against this backdrop of local and national political, social, and cultural upheaval, a narrative of Ali's racial and, more importantly, religious "convictions" is constructed. Particular attention is given to framing the socio-political context for Ali's (in) famous conscientious objection to being subject to the draft for the Vietnam War. Indeed, a large illustrated time-line of the Vietnam War extends across a back wall of the exhibit, with a digital display of scrolling facts and statistics from the war lining the bottom of the wall. In this space, quotations representing the shifting views of politicians concerning the war are displayed on the floor of the museum, while quotations detailing Ali's "convictions" are positioned above visitors' heads.

Many visitors may be familiar with Ali's more widely circulated quotations such as, "I ain't got no quarrel with them Vietcong." However, lesser known quotes that explain Ali's "convictions" concerning the implications of the war for black Americans are employed to invite critical reflection on domestic issues of racial injustice and their relationship to broader neo-colonial politics embedded in the United States' foreign policies on warfare. Along these lines, "Why should they ask me to put on a uniform and go ten thousand miles from home and drop bombs and bullets on brown people in Vietnam while so-called Negro people in Louisville are treated like dogs and denied simple human rights ... If I thought the war was going to bring freedom and equality to 22 million of my people, they wouldn't have to draft me. I'd join tomorrow" is a strategically and prominently displayed quotation in the exhibit. Furthermore, beyond the racial politics of his conscientious 
objection, the exhibit displays Ali's even lesser known, or understood religious convictions for refusing to go to war: "I refuse to be inducted into the Armed Forces of the Unities States because I claim to be exempt as a minister of the religion of Islam." In a more "spiritual" register that anticipates Spirituality as a culminating core principle, visitors can look above head to read Ali's query, "How can I kill somebody when I pray five times a day for peace?"

Indeed, Ali's "conviction" is voiced most forcefully in his conscientious objection to the war, and his insistence that it is based upon his understanding of the teachings of Elijah Muhammad, Islam, and the Holy Qu'ran. Again, the core principle of Spirituality is engaged in the midst of, and as a form of, Conviction. Written and oral testimony is strategically displayed in this politically charged space, conveying Ali's insistence that by objecting to the war he is "standing up for my religious beliefs even in the face of imprisonment." Moreover, visitors are presented with what are intended to be understood as Ali's deepest convictions, given voice in his insistence, "I'm ready to die (for my religious beliefs, rather than betray them by fighting in the Vietnam War)." By contrast, visitors are presented with Ali's challenge to a nation that charged him with being an "unpatriotic, draft-dodger," when Ali questions the integrity of those who demand that he fight for "democracy" in Vietnam while "you won't even stand up for me and my religion right here in America."

Through such curatorial strategies, the Conviction exhibit makes use of "religion," and/or "spirituality" in ways intended to lend a greater sense of moral authority and legitimacy to Ali's more widely known racial reasoning against his participation in the Vietnam War. Moreover, these references to Ali's religious convictions, including the aforementioned quotation, "How can I kill somebody when I pray five times a day for peace?" encourage a reconsideration of stereotypical, and Islamophobic ideas about Islam as a violent ideology (and hardly a "religion" at all) perpetuated in the mass media. The Conviction exhibition, with the intensity of the affective charge of its displays, can be understood as functioning to evoke an emotional response in visitors that encourages a greater sense of wrestling with the sort of moral, ethical, and/or religious "convictions" that might be demanded by contemporary socio-political conflicts. The deployment of multiple signifiers of contested issues of "race" and "religion" in this exhibit encourages visitors to come to terms with the relationship of these categories of identification to their own sense of "conviction."

\section{7. “The Only Religion That Matters Is Love": Representing Spirituality as an Inclusive, Expansive, Global, and Socially Transformative Category of Identity}

The politically charged Conviction exhibit, with its graphic portrayal of racial riots and the devastation of war, sets up a rather striking contrast to the Spirituality Pavilion, which is intended to be the culminating experience of the Core Principles section of the museum. Spatially, the Spirituality Pavilion is slightly, but distinctly, set apart from the other exhibits by a partial screen or "veil," which can be understood as signifying a transition from "profane" to "sacred" space within the museum. Once inside the exhibit space, eight reclining seats, positioned in a circular formation, invite visitors to shift their bodies into a relaxed and meditative posture. This spatial design, particularly the opportunity to recline, offers visitors a reflective and potentially rejuvenating space, which is likely an intentional curatorial strategy that anticipates physically and emotionally weary visitors entering the space following the most intense of the museum's exhibitions. Moreover, by shifting the bodily comportment of patrons from standing to reclining, and directing their gaze upwards, the Center invites visitors to a posture of openness (and perhaps "submission") for a viewing of an audio-visual presentation, accompanied by narration, which is projected above head and details Ali's evolved perspectives on religion and spirituality.

The audio-visual presentation in this exhibit space offers visitors an autobiographical account (given voice by a narrator) of Ali's ever-expanding understanding of his relationship to Allah, other religious traditions, and all of creation. As such, the exhibit presents a more expansive view of Ali's spirituality, which was foreshadowed in previous exhibits. Promoting an atmosphere of tranquility and tolerance, this exhibit space is designed to present Ali's embrace and practice of Islam 
as an expression of peace that offers a stark contrast to dominant narratives of Islam, which emphasize extremism and violence. The question of "Who is the greatest?" which opened the initial Confidence exhibit is revisited in this concluding audio-video presentation. This time, however, Ali insists that Allah has shown him that "He" is the greatest, and not Ali.

Upon entering the Spirituality Pavilion, patrons should have been well acquainted with the socio-political and religious issues influencing Ali's conversion to the Nation of Islam. They have also likely been exposed to some of the more acerbic rhetoric of the NOI. Likely anticipating mixed responses to previous accounts of Cassius Clay's conversion from Christianity to the Nation of Islam, this exhibit calls attention to Ali's earliest spiritual influence-his mother-who is described as a "devout Christian" and the one who first cultivated Ali's "spiritual center." This interpretive device, which appears on the signage that marks entrance into the space, uses an appeal to maternal love and guidance as well as the cultural capital of Christianity to encourage a more favorable reading of Ali's religious convictions and spiritual journey. Elsewhere in the exhibit, the maternal appeal is employed as a curatorial strategy to introduce Ali's more expansive views on religion and spirituality:

My mother was a Baptist. She believed Jesus was the son of God, and I don't believe that.

But even though my mother had a religion different from me, I believe that on Judgment

Day my mother will be in heaven. There are Jewish people who lead good lives' and when they die I believe they're going to heaven. If you're a good Muslim, if you're a good Christian, if you're a good Jew' it doesn't' matter what religion you are, if you're a good person you'll receive God's blessing.

The walls of this exhibit are lined with quotations and scriptures from a broad range of spiritual traditions, which can be understood to communicate and/or reinforce the "script" that all of the world's religions contain truth, share many values in common, and are deserving of equal respect. Quotations and scriptures from the world's religions are strategically displayed around six broad themes: love, justice, hope, peace, the Golden Rule, and spiritual practice. This curatorial strategy is intended to emphasize commonalities across religions and cultures of the world. To advocate this posture of pluralism and inter-religious dialogue, Ali is quoted as confessing, "the only religion that matters is the real religion-love."

This more liberal and pluralistic vision of religion is in stark contrast with Ali's earlier embrace of the more particularist vision of religion, articulated by Elijah Muhammad's Nation of Islam. Yet, the significance of the Nation of Islam's message of religious piety and racial pride in Ali's spiritual (trans-)formation is reiterated and reaffirmed, before detailing Ali's embrace of Sunni Islam following the death of Elijah Muhammad in 1975. Indeed, a large time line of "Ali's Spiritual Journey" extends across the back wall of the exhibit space, detailing the many stages in Ali's process of religious subject formation. The fact that the Nation of Islam was liberating for Ali at a particular point in his journey is underscored with appreciation. Yet, Ali's eventual embrace of Sunni interpretations of Islam, along with a number of other African Americans who followed that spiritual path, is represented in a manner that encourages equal respect. On the time line, and in the film, images of Ali engaged in spiritual practices, such as his pilgrimage to Mecca as well as his performances of Sunni practices of "salat" (prayer) provide a more visual, non-discursive display of Ali's spiritual development than previous displays, which tended to focus more on discursive and verbal articulations of Ali's religious views. Taken together, Ali's unwavering commitment to the "religion" of al-Islam is established in this exhibit, while insisting that that Ali's "spirituality" transcends his own particular "religious" commitments.

It is worth noting at this point that the category of "spirituality" appears to be strategically deployed throughout the Ali Center, and in this exhibit in particular, as a means of disrupting potentially reified understandings of the category of "religion" in general, and the religious tradition of Islam in particular. By presenting Ali's process of maturation in terms of "spirituality," here described as both more expansive than as well as thoroughly embedded in and through particular religious traditions, the Center presents a vision of Ali's embodiment of Islam intended to resonate with a wide range of visitors who may be more conservative, Christian, and/or non-religious in their own 
religious views. As such, the Ali Center can be understood to be encouraging an understanding of "spirituality" that is in line with what scholars have described as "a growing sense that different religious traditions have spiritual wisdom that is non-exclusive and may be shared." (Sheldrake 2012, p. 96). More interesting is the possible interpretation of the Center's representation of a "spirituality" that transcends "religion" as presenting a positive view of more recently studied phenomenon such as "dual belonging" or "interspirituality." (Sheldrake 2012, p. 96). While these latter ways of approaching spirituality may appear to be out of step with Ali's own devotion to the particularity of Islamic practice, Philip Sheldrake's alternative way of conceiving "interspirituality," as "(demanding) a commitment to walk a spiritual path with openness and a capacity to be challenged and transformed by what one meets on the way," not only seems to capture the spirit of Ali, but also the intentions of the Ali Center's Spirituality Pavilion.(Sheldrake 2012, p. 112).

In this representation of Ali's more expansive religious identification, however, it is worth asking what message this exhibit offers visitors concerning the relationship between "spirituality" and the ongoing issues of racial injustice faced by African Americans, which were raised in earlier exhibits. In a similar manner as Eddie S. Glaude Jr. considers that the affiliation of a number of African Americans with Sunni Islamic traditions, over previous identifications with the more racialized Nation of Islam, represents an "open question" concerning "how they articulate their commitment to Islam and the realities of racism in this country," the Spirituality Pavilion represents a similarly "open question" concerning the message that the Ali Center intends to communicate to is visitors concerning the relationship between a mode of spirituality defined in rather universalist terms and the more particularistic issues concerning "race" in the United States. (Glaude 2014, p. 114).

Whatever else the Ali Center intends to communicate about this core principle, the Spirituality Pavilion presents a thoroughly global view of religion and spirituality. This global emphasis suggests that the Ali Center is invested in advocating a perspective on religion that encourages interreligious dialogue among people of faith from a vast array of religious traditions the world over. As Sheldrake explains, such an approach to spirituality that emphasizes dialogue and reconciliation can be better understood as being influenced by "the increasing globalization of religious faiths away from their traditional cultural bases, a growing awareness of a religiously plural world, a commitment to the respect for cultural diversity, and, in some parts of the world, the need to address the close connections between violence and religious antagonisms." (Sheldrake 2012, p. 104). In this sense, the core principle of Spirituality, as curated by the Ali Center, is represented as a more inclusive and expansive category of identification than either "race" or "religion." As such, this principle is strategically employed as a key to understanding, and taking inspiration from, Ali's global humanitarian work, which is at the heart of the Center's curatorial "script."16

\section{Implications}

In this article, I have argued for the significance of considering cultural institutions, such as the Muhammad Ali Center as sites where meanings and values associated with categories of difference, such as "race" and "religion" are mediated, negotiated, contested and advocated. Throughout the article, I have explored the representational and curatorial strategies of the Muhammad Ali Center, with particular attention to re-presentations of issues of social concern related to racial injustice and

16 "Global Citizenship," along with "Education," and "Gender Equality," are listed as three central programmatic initiatives of the Muhammad Ali Center. These programmatic initiatives are cross-cutting themes, that inform and expand the curation of, and initiatives flowing from the "Core Principles." "Global Citizenship" is a critical theme, that runs throughout the Ali Center and functions to reinforce the image of Muhammad Ali as a global humanitarian, who fought for the well-being of marginalized and disenfranchised people all over the world, from poor black folks in the urban United states to desperate people in the slums of India. The Center's collaborative efforts with local organizations such as Interfaith Paths to Peace (i.e., Festival of Faiths), Kentucky Refugee Ministries (i.e., Day of Dignity) reinforce the interconnected themes of "spirituality" and "global citizenship," while rooting these compassionate ways of being in the world in the local context of Louisville, KY, USA. 
religious intolerance. I have made use of theoretical and analytical tools of cultural studies, museum studies, and religious studies in order to offer a descriptive analysis of how the Ali Center makes strategic use of its "six core principles" in order to encode issues of cultural difference, including especially the contested categories of "race," and "religion," into the "script" of the Center's museum space. Throughout the article, I have called attention to the range of potential messages and meanings encouraged and/or advocated by the Ali Center's re-presentations of the interplay of "race" and "religion." As I have noted above, a fuller account of the social effects of such representational strategies would require additional research that attends to audience reception and responses to the Center's exhibition of its six core principles.

Nevertheless, it is possible to draw out some provisional implications, if not conclusions, from this research. The representational and curatorial strategies of the Ali Center, which present Ali's seemingly apolitical six core principles as deeply contextualized challenges to the status quo, prior to engagements with his boxing career proper, challenges visitors to the Center to confront issues of race and religion at every turn. If Ali is widely hailed as a cultural hero in the realm of athletics, many regard his religious and racial identifications as deviant, provocative, and/or outright offensive (Hart 2008, p. ix). Put another way, the Ali Center, as a museum space dedicated to a Black Muslim American, must negotiate the historical tension between white patronage and representations of black self-determination (Cahan 2016, p. 5). Of course, the potential for alienation is not only among white patrons, many African Americans and other nonwhites regard Ali's religious identifications and the black nationalist ideologies that informed his initial conversion to the Nation of Islam with equal suspicion as whites-though perhaps for different reasons. This has undoubtedly led to a deliberate framing and strategic representation of the life and legacy of Ali. Remarkably, however, such representational politics have not led to an avoidance of the more provocative and controversial issues in Ali's narrative, namely his outspokenness on matters of race and religion. Nevertheless, the Center has meticulously managed its public perception, and has carefully curated a balanced experience of invitation and provocation for its visitors (Dean 1994, p. 7).

While the Muhammad Ali Center has had to negotiate the potentially volatile terrain of race and religion, without unnecessarily alienating donors and patrons-and as a result undermining its potential to affect social change- the Center has used strategic representational and curatorial practices and innovative programming to press public discourse around racial injustice and religious intolerance in more progressive directions. Such curatorial strategies, coupled with ongoing programmatic events, continue to press for critical engagements with the provocative legacy of Ali that demand a reckoning with the ways that anti-blackness, Islamophobia, anti-Immigration, and other forms of xenophobia that Ali addressed during his lifetime, continue to affect marginalized communities in the United States and throughout the globe.

Along these lines, the Ali Center can be understood to be engaged in the work of "(Re) Framing Conversations," which Richard Sandell describes in his work Museums, Prejudice and the Reframing of Difference. (Sandell 2006, pp. 173-96). Sandell argues:

Museum exhibitions present audiences with authoritative, credible and permissible ways of thinking and talking about difference. These ways of thinking and talking have more than symbolic significance-they shape normative truths, social relations and material conditions; they can inhibit, or potentially nurture, possibilities for equity, mutual understanding and respect. (Sandell 2006, p. 175).

While Sandell remains attentive to, and appreciative of, concerns that cultural institutions, and museums in particular, not devolve into partisan politics that engage in ideologically rigid modes of indoctrination, he nevertheless argues that such institutions should not avoid engaging with social issues and advocating morally principled standpoints. With reference to the Ali Center, I would argue that the strategic negotiation of their approach to addressing issues of racial injustice and religious intolerance is consistent with Sandell's argument for institutions that "(acknowledge) their portrayals of difference have real effects (and) can provide opportunities for debating the challenging questions 
which are an inevitable consequence of inequitable and increasingly diverse societies." (Sandell 2006, p. 196).

As I have demonstrated above, the Ali Center uses representation and curatorial strategies that, while avoiding an overly didactic and dogmatic approach to social justice issues, critically and reflexively engage "race" and "religion" in complex ways. The use of aural, visual, and filmic displays to exhibit issues as broad ranging as black internalized oppression and black nationalist gender politics as well as anti-war demonstrations and global humanitarian concerns functions to illicit in visitors a range of potential responses to the roles of "race" and "religion" in shaping human conceptions of and responses to cultural difference and conflict. While the Ali Center can certainly be understood as encoding a "script" throughout its museum exhibit space that encourages a more universalizing message of global humanitarian concern, the Center nevertheless presents a range of more particular issues of social concern, involving racial injustice and religious intolerance that hold out the potential to "re-frame conversations" among diverse communities, both within and beyond the museum space.

Of course, the permanent exhibits, surrounding the core principles, only do so much of this work. However, temporary exhibits, educational programs, and community engagement programming initiatives expand the work of the Center in ways that challenge perspectives and policies concerning an even broader range of issues that involve the intersectionality of "race" and "religion" with issues of gender, class, sexuality, age, ability and a range of other categories of difference. ${ }^{17}$ As a result, the Ali Center represents an important site for continued research on the role of cultural institutions in ongoing struggles for social justice concerning issues of "race" and "religion" through their strategic displays of various expressions of African American religions. Thus, I submit that by taking seriously the social agency, representational and programmatic strategies of cultural institutions, such as the Ali Center, scholars of African American religion and culture can gain a better understanding of alternative ways that meanings associated with, and understandings of "race" and "religion" are constructed, contested, and potentially transformed in public discourse and practice.

Conflicts of Interest: The author declares no conflicts of interest.

\section{References}

Cahan, Susan A. 2016. Mounting Frustrations: The Art Museum in the Age of Black Power. Durham: Duke University Press.

Clover, Darlene. 2017. Exhibitions of Power: Participatory Visual Practices in Contemporary Museums. New Directions for Adult and Continuing Education 2017: 83-91. [CrossRef]

Coffee, Kevin. 2006. Museums and the Agency of Ideology: Three Recent Examples. Curator: The Museum Journal 49: 435-48. [CrossRef]

Cooper, Brittany. 2017. Beyond Respectability: The Intellectual Thought of Race Women. Urbana: University of Illinois Press.

Curtis, Edward E. IV. 2006. Black Muslim Religion in the Nation of Islam: 1960-1975. Chapel Hill: University of North Carolina Press.

Curtis, Edward E. IV, and Danielle Brune Sigler. 2009. The New Black Gods: Arthur Fauset and the Study of African American Religions. Bloomington: Indiana University Press.

Dean, David. 1994. Museum Exhibition: Theory and Practice. New York: Routledge.

17 The Ali Center engages in a range of programmatic and public initiatives, including a film series which regularly features films dealing with issues of social justice followed by community discussions, led by academics and /or activists; and helps to facilitate difficult conversations in the community concerning what it means to attempt to create justice and compassionate communities across multiple axes of difference, including geo-political space in the context of increasingly contested globalization. The "Daughters of Greatness" lecture series features a range of speakers addressing issues related to "gender equality." Likewise, the "Humanitarian Awards" series features internationally recognized young people who are advancing the core principles of the Ali Center. Moreover, the Center's collaborative efforts with organizations such as Interfaith Paths to Peace (i.e., Festival of Faiths) and Kentucky Refugee Ministries (Day of Dignity) reinforce the themes of "Spirituality" and "Global Citizenship," while rooting these compassionate ways of being in the world in the local context of Louisville. This is a necessarily partial, but representative, list of the multiple programming and public initiatives that the Ali Center sponsors towards the ends of advancing issues of social justice. 
Dubin, Steven. 1999. Displays of Power: Memory and Amnesia in the American Museum. New York: New York University Press.

Gardell, Mattias. 1996. In the Name of Elijah Muhammad: Louis Farrakhan and the Nation of Islam. Durham: Duke University Press.

Glaude, Eddie S. 2014. African American Religion: A Very Short Introduction. New York: Oxford University Press. Hart, William D. 2008. Black Religion: Malcolm X, Julius Lester and Jan Willis. New York: Palgrave MacMillan. Hauser, Thomas. 1991. Muhammad Ali: His Life and Times. New York: Simon and Schuster Paperbacks.

Higgenbotham, Evelyn Brooks. 1993. Righteous Discontent: The Women's Movement in the Black Baptist Church, 1880-1920. Cambridge: Harvard University Press.

Johnson, Sylvester A. 2009. Religion Proper and Proper Religion: Arther Fauset and the Study of African American Religions. In New Black Gods: Arthur Huff Fauset and the Study of African American Religions. Edited by Edward E. Curtis IV and Danielle Brune Sigler. Bloogmington: Indiana University Press.

Johnson, Sylvester A. 2015. African American Religions, 1500-2000: Colonialism, Democracy, and Freedom. New York: Cambridge University Press.

Noordegraaf, Julia. 2004. Strategies of Display: Museum Presentation in Nineteenth-and Twentieth-Century Visual Culture. Rotterdam: Museum Boijmans Van Beuningen, Rotterdam: NAi Publishers.

Orange, Jenifer A. 2012. Museums, Equality and Social Justice. Curator: The Museum Journal 55: 373-82. [CrossRef] Sandell, Richard. 2006. Museums, Prejudice and the Reframing of Difference. New York: Routledge Press.

Sandell, Richard. 2012. Museums, Equality and Social Justice. New York: Routledge Press.

Sheldrake, Philip. 2012. Spirituality: A Very Short Introduction. New York: Oxford University Press.

Younge, Gary. 2012. The margins and the mainstream. In Museums, Equality, and Social Justice. Edited by Richard Sandell and Eithne Nightingale. New York: Routledge Press, pp. 105-13.

(C) 2017 by the author. Licensee MDPI, Basel, Switzerland. This article is an open access article distributed under the terms and conditions of the Creative Commons Attribution (CC BY) license (http:/ / creativecommons.org/licenses/by/4.0/). 